\title{
GC-MS Analysis and Antimicrobial Effects of Methanol Stem Bark Extract of Trilepisium madagascriense DC
}

\author{
Olufunmiso 0. Olajuyigbe ${ }^{1}$, Faith 0 . ljeyan ${ }^{1}$, Morenike 0. \\ Adeoye-Isijola ${ }^{1}$
}

\begin{abstract}
${ }^{1}$ Department of Microbiology, School of Basic \& Applied Sciences, Babcock University, PMB 4005, Ilisan Remo, Ogun State, Nigeria
\end{abstract}

\begin{abstract}
The therapeutic potentials of methanol stem bark extract of Trilepisium madagascriense was determined using Gas Chromatography-Mass Spectrometry to identify its bioactive compounds of pharmaceutical importance while the antimicrobial activities were assayed in vitro by agar well diffusion and macrobroth dilution techniques against different microbial isolates. The mass spectra of the identified compounds in the extract at different retention time showed the presence of ethyl iso-allocholate, (3ß,5Z,7E)-9,10-Secocholesta-5,7,10(10)triene-3,24,25-triol, 2,6-Dimethoxyamphetamine, 4-Hexenoic acid, 4-methyl-6-(fluorodimethylsilyl)-6-trimethysily, 2-methoxy-4-(methoxymethyl)-Phenol, 2-methoxy-1,4-Benzenediol, 2,4-Dimethoxyphenol, Indole, Paromomycin, Hydroquinone and Tetrahydro-N-[(tetrahydro-2-furanyl)methyl-2-Furanmethanamine amongst other bioactive compounds of therapeutic potentials. This extract showed antimicrobial activities. At the lowest concentration of 25 $\mathrm{mg} / \mathrm{ml}, 100 \mu \mathrm{l}$ of the extract produced inhibition zones ranging between 14 and $18 \pm 1.0 \mathrm{~mm}$ and inhibition zones ranging between 18 and $28 \pm 1.0 \mathrm{~mm}$ in all the isolates at the highest concentration of $100 \mathrm{mg} / \mathrm{ml}$. While the bacterial MICs ranged between 1.25 and $5 \mathrm{mg} / \mathrm{ml}$ and the MBCs ranged between 2.5 and $10 \mathrm{mg} / \mathrm{ml}$, the fungal MICs ranged between 0.098 and $12.5 \mathrm{mg} / \mathrm{ml}$ while the MFCs ranged between 0.781 and $<25 \mathrm{mg} / \mathrm{ml}$. With exception of $\mathrm{MIC}_{\text {index }}$ of Klebsiella pneumoniae ATCC 10031 which was equal to 4, the $\mathrm{MIC}_{\text {index }}$ of other isolates ranged between 1 and 2. Klesbiella pneumoniae ATCC 10031 and Proteus vulgaris CSIR 0030 had the highest MICs of $1.25 \mathrm{mg} / \mathrm{ml}$, followed by B. cereus ATCC 10702, Staphylococcus aureus ATCC 6538, Pseudomonas aeruginosa ATCC 19582, Enterococcus faecalis ATCC 29212 and Bacillus subtilis KZN with MICs of $2.5 \mathrm{mg} / \mathrm{ml}$ while Escherichia coli ATCC 25922, Enterococcus cloacae ATCC 13047, Enterococcus faecalis KZN, Shigella sonnei ATCC 29930, Klebsiella pneumoniae $\mathrm{KpFa}$, Staphylococcus aureus $\mathrm{SaFa}$, Escherichia coli EcFa and Pseudomonas aeruginosa $\mathrm{PmFa}$ had the least MICs of $5.0 \mathrm{mg} / \mathrm{ml}$. Enterococcus faecalis KZN, Bacillus subtilis KZN and Proteus vulgaris CSIR 0030 had the highest MBCs of $2.5 \mathrm{mg} / \mathrm{ml}$. Although Candida albicans had MICs ranging between 0.098 $\mathrm{mg} / \mathrm{ml}$ and Candida tropicalis had the least MICs of $12.5 \mathrm{mg} / \mathrm{ml}$, the MFCs were $0.781 \mathrm{mg} / \mathrm{ml}$ and $25 \mathrm{mg} / \mathrm{ml}$. This study shows that the pharmacological effects of Trilepisium madagascriense depends on bioactive compounds identified while this plant is a source for isolating novel drugs having significant therapeutic potentials.
\end{abstract}

Keywords: Antimicrobial, bioactive phytoconstituents, betulin, paromomycin, pharmacological effects

\section{INTRODUCTION}

Before the introduction of chemical medicines, man relied on the healing properties of medicinal plants (Ahvazia et al., 2012), which took the form of crude drugs such as tea, poultices, powders and other herbal formulations (Samuelsson and Bohlin, 2004). The particular plant to be used and the mode of application for particular ailments were passed down through oral history (Balunas and Kinghorn, 2005). An estimated 80 percent (4.8 billion people) of the world's population depend on medicinal plants for health care because they are generally free or readily available at very affordable cost (Listorti and Doumani, 2001). The medicinal qualities of plants are of course due to chemicals. Plants synthesize many compounds called primary metabolites that are critical to their existence. These includes proteins, fats and carbohydrates that serve a variety of purposes indispensable for sustenance and reproduction, not only for the plants themselves, but

This article is published under the terms of the Creative Commons Attribution License 4.0

Author(s) retain the copyright of this article. Publication rights with Alkhaer Publications.

Published at: http://www.ijsciences.com/pub/issue/2017-08/

DOI: 10.18483/ijSci.1366; Online ISSN: 2305-3925; Print ISSN: 2410-4477 
also for animals that feed on them. Plants also synthesize a dazzling array of additional components, called secondary metabolites, whose function has been debated. Many secondary metabolites are "antibiotic" in a broad sense, protecting the plants against fungi, bacteria, animals and even other plants (Small and Catling, 1999). Drug discovery from medicinal plants led to the isolation of early drugs such as cocaine, codeine, morphine, digitoxin and quinine from Erytheoxylon coca leaves, Opium poppy latex and Digitalis leaves respectively (Balunas and Kinghorn, 2005).

In recent years, antimicrobial drug resistance in human pathogenic bacteria has been commonly reported from all over the world (Doughari, 2012). In developing and developed countries, this situation is alarming due to prolong and indiscriminate use of antibiotics. This has resulted in the development of multidrug resistance (Alp, 2007; Tiwari et al., 2014) in microbes especially bacteria such as methicillin resistant Staphylococcus aureus, Helicobacter pylori and MDR Klebsiela pneumoniae (Upadhyay et al., 2014). Therefore, alternative antimicrobial strategies are urgently needed as the efficacy of antibiotics is now significantly limited and, thus, has led to a reevaluation of the therapeutic use of ancient remedies such as plants (Chowdhury et al., 2013).

Secondary metabolites which are low molecular weight compounds have provided numerous pharmaceutical agents. While their synthesis is not normally required for growth, development or reproduction of plants (Harborne, 1984; Rosenthal, 1991 ), they protect plants from any possible harm in the ecological environment (Stamp, 2003) and other interspecies predation (Samuni-Blank et al., 2012). They, also, protect plants from disease and damages as well as contributing to the plant's colour, aroma and flavour (Saxena et al., 2013). Phytochemicals which are primary and secondary compounds include terpenoid, alkaloids, tannins and phenolic compounds exhibiting various important pharmacological activities (Wadood et al., 2013). Though phytochemical screening is a process of tracing plant constituents, it is of paramount importance to qualitatively and quantitatively identify new source of therapeutically and industrially valuable compounds having medicinal values (Geetha and Geetha, 2104). Thus, various phytochemical analyses have been used for the identification of specific phytochemicals such as furfural, catechol, indole and benzoic acid (Doughari, 2012; Gracelin et al., 2013). Of the quantitative phytochemical analyses, Gas Chromatography-Mass Spectrometry (GC-MS) analysis is of importance. Gas chromatography separates the components of a mixture and mass spectrometry characterizes each of the components individually (Bull, 2008). Literature search reveals that most of the predominant compounds identified in such analysis in different crude extracts are biologically active molecules (Kar et al., 2007; Cock et al., 2009; Lucantoni et al., 2010; Hossain and Nagooru, 2011).

Trilepisium madagascriense D.C. Leeuwenberg (Moraceae), also known as Urnfig or False-fig is a forest tree belonging to the Moraceae family that grows to a height of about $30 \mathrm{~m}$ and is usually found in riverine ground, lowlands and sub-mountainous forest in Tropical Africa. It is propagated by bud grafting and its leaves are domestically consumed as vegetable (Ampa et al., 2013). The stem bark is traditionally used to treat venereal diseases, arthritis, rheumatism, diarrhoea and dysentery, while the roots are used against cutaneous and subcutaneous parasitic infections (Teke et al., 2010). Pharmacologically, while the methanol extract from the leaves of $T$. madagascariense was reported to inhibit the growth of Staphylococcus aureus (Sabrina et al., 2006) and the ethanol extract of the leaves showed antidiabetics properties (Ampa et al., 2013), isoliquiritigenin, a compound isolated from ethylacetate fraction of the methanol stem bark extract of this plant was indicated to possess antidiarrheal activities (Teke et al., 2010). Also, trilepisflavan, dihydrokaemferol and 8-C-glucopyranosylapigenin compounds isolated from this plant have been reported to possess significant antimicrobial properties (Ango et al., 2012). The methanol extract of the stem bark was also reported to possess antifungal activity against Candida guillermondi (Kuiate, 2011). To identify and enumerate the bioactive compounds of therapeutic value of $T$. madagascriense, this study was aimed at investigating the phytochemical constituents and antimicrobial properties of the stem bark methanol extract of $T$. madagascriense D.C.

\section{MATERIALS AND METHODS}

\section{Collection and authentication of plant sample}

Stem bark of Trilepisium madagascriense was collected from Ilishan, Ogun state, Nigeria, on the $17^{\text {th }}$ of April, 2015. The samples collected were identified and authenticated ethnobotanically and confirmed by Dr. O.O. Olajuyigbe at the Department of Microbiology, Babcock University, Nigeria while the specimen voucher is being prepared.

\section{Extract preparation}

The bark sample was air-dried at room temperature, pulverized with a milling machine and extracted as described by Olajuyigbe and Afolayan, (2012). Briefly, exactly $200 \mathrm{~g}$ of the pulverized sample was extracted with $1000 \mathrm{ml}$ of methanol for $72 \mathrm{~h}$ with continuous agitation (Stuart Scientific Orbital Shaker, 
Staffordshire, UK). The extract was filtered through Whatman No. 1 filter paper and concentrated under reduced pressure at $40^{\circ} \mathrm{C}$ using a rotary evaporator (Laborota 4000-efficient, Heldolph, city, Germany). The extraction was done for two more consecutive times. The crude extract collected was dried at room temperature to a constant weight. The extract was later dissolved in methanol to the required concentrations for bioassay analysis. The reconstituted extract solution was filtered through $0.45 \mu \mathrm{m}$ membrane filter and tested for sterility after membrane filtration by introducing $2 \mathrm{ml}$ of the extract in $10 \mathrm{ml}$ of sterile nutrient broth before being incubated at $37^{\circ} \mathrm{C}$ for $24 \mathrm{~h}$. A sterile extract was indicated by the absence of turbidity in the broth after the incubation period.

Gas Chromatography-Mass Spectrometry (GCMS) analysis of methanol extract

The GC-MS analysis was carried out using GC-MSQP 2010 Plus Shimadzu system and Gas chromatograph interfaced to a mass spectrometer instrument employing the following conditions: Column Elite-1 fused silica capillary column (30m x $0.25 \mathrm{~mm} 1 \mathrm{D} \times \mu \mathrm{df}$, composed of $100 \%$ dimethyl polysiloxane). For GC-MS operation, an electron ionization system with ionization energy of $70 \mathrm{eV}$ was used. Helium gas $(99.99 \%)$ was used as the carrier gas at constant flow rate $1 \mathrm{ml} / \mathrm{min}$ and an injection volume of $2 \mu \mathrm{l}$ was employed (Split ratio of 10:1) injector temperature $-250^{\circ} \mathrm{C}$; ion-source temperature $280^{\circ} \mathrm{C}$. The oven temperature was programmed from $110^{\circ} \mathrm{C}$ (Isothermal for $2 \mathrm{~min}$ ) with an increase of $10^{\circ} \mathrm{C} / \mathrm{min}$ to $200^{\circ} \mathrm{C}$ then $5^{\circ} \mathrm{C} / \mathrm{min}$ to $280^{\circ} \mathrm{C} / \mathrm{min}$, ending with a $9 \mathrm{~min}$ isothermal at $280^{\circ} \mathrm{C}$. Mass spectra were taken at $70 \mathrm{eV}$; a scan interval of $0.5 \mathrm{~s}$ and fragments from 40 to $550 \mathrm{Da}$. Total GC running time was $60 \mathrm{~min}$. The relative percentage amount of each component was calculated by comparing its average peak area to the total area. Software adopted to handle mass spectra and chromatogram was a Turbo-Mass-OCPTVS-Demo SPL software. The identification of the compounds was based on the comparisons of their mass spectra with NIST Ver. 2.0 year 2008 library WILEY8, FAME (Sriranmsridharan, 2011).

\section{Test organisms and inocula preparation}

The bacteria used in this study included Enterococcus faecalis ATCC 29212, Klebsiella pneumoniae ATCC 10031, Bacillus subtilis KZN, Staphylococcus aureus ATCC 6538, Bacillus cereus ATCC 10702, Pseudomonas aeruginosa ATCC 19582, Escherichia coli ATCC 25922, Proteus vulgaris CSIR 0030, Enterobacter cloacae ATCC 13047 and Shigella sonnei ATCC 29930. The clinical bacterial isolates include Enterococcus faecalis KZN, Klebsiella pneumoniae $\mathrm{KpFa}$, Staphylococcus aureus $\mathrm{SaFa}$,
Escherichia coli $\mathrm{EcFa}$, and Pseudomonas aeruginosa $\mathrm{PmFa}$. The clinical fungal isolates used include Candida albicans CA4, Candida tropicalis CT4, Candida albicans CA15, Candida albicans CA6 and Candida albicans CA23. Each bacterial isolate was maintained on nutrient agar slants and was recovered for testing by growth in nutrient broth for $24 \mathrm{~h}$ while the fungal isolates were maintained on Saboraud dextrose agar slants and was recovered by growth in Saboraud dextrose broth for $72 \mathrm{~h}$. Bacteriologically, each of the clinical strains was streaked on nutrient agar which was incubated overnight at $37^{\circ} \mathrm{C}$ for $24-$ $48 \mathrm{~h}$ (Forbes et al., 2007). These isolates were subjected to Gram staining, microscopic appearance, colony morphology and biochemical tests such as tube coagulase test according to standard protocols (Holt et al., 1994; Cheesbrough, 2002; Cheesbrough, 2009). The inocula of the test isolates were prepared using the colony suspension method (EUCAST, 2000). Colonies picked from $24 \mathrm{~h}$ old cultures grown on nutrient agar were used to make suspensions of the test organisms in saline solution to give an optical density of approximately 0.1 at $600 \mathrm{~nm}$. The suspension was then diluted $1: 100$ by inoculating 9.9 $\mathrm{ml}$ of sterile nutrient broth with $100 \mu \mathrm{l}$ of the bacterial suspension and thoroughly agitated before being used.

\section{Antimicrobial assay by agar diffusion (inhibition zones) methods}

For the initial determination of the antibacterial activity of the crude methanol extract of Trilepisium madagascriense, the susceptibility screening of the test bacteria to the extract was determined by using the modified Kirby-Bauer diffusion technique (Cheesbrough, 2002). This method involves swabbing Mueller-Hinton agar (Lab M Ltd, Quest Park, Lancashire, UK) plates with the resultant saline suspension of each adjusted bacterial strain. For the antifungal assay, $1 \mathrm{~cm}^{2}$ of seven day old fungal cultures was dropped in sterile distilled water and vortexed for $2 \mathrm{~min}$ to release the fungal spores. Saboraud dextrose agar plates were seeded with 200 $\mu \mathrm{l}$ of the fungal spore solutions, allowed to stand for $1 \mathrm{~h}$ on the laboratory bench. Wells, later filled with $100 \mu \mathrm{l}$ of different concentrations of the extract $(20$ $\mathrm{mg} / \mathrm{ml}, 40 \mathrm{mg} / \mathrm{ml}, 60 \mathrm{mg} / \mathrm{ml}, 80 \mathrm{mg} / \mathrm{ml}$, and 100 $\mathrm{mg} / \mathrm{ml}$ ) taking care not to allow spillage of the solutions onto the agar surface, were then bored into the agar medium with a heat sterilized $6 \mathrm{~mm}$ cork borer. The culture plates were allowed to stand on the laboratory bench for $1 \mathrm{~h}$ to allow proper diffusion of these solutions before being incubated at $37^{\circ} \mathrm{C}$ for 24 $\mathrm{h}$ and $27^{\circ} \mathrm{C}$ for $72 \mathrm{~h}$ for fungal cultures. Wells in blank Mueller Hinton agar containing 10\% methanol representing the final concentration of the methanol in the test plates without the extract served as positive control. The determinations were done in duplicates. 
After $24 \mathrm{~h}$ of incubation, the plates were examined for the presence of inhibition zones. The diameters of the inhibition zones produced by each concentration of each of the extract were measured in millimetres (Wikler, 2007) and interpreted using the Clinical and Laboratory Standard Institute Zone diameter interpretative standards (Wikler, 2008).

Macrobroth dilution for determining minimum inhibitory concentration (MIC)

Minimum inhibitory concentration (MIC) defined as the lowest concentration which resulted in maintenance or reduction of inoculums' viability was determined by serial tube dilution technique (Iwaki et al., 2006; Khan et al., 2007) for each of the test isolates. Different concentrations ranging from 0.039 $\mathrm{mg} / \mathrm{ml}$ to $20 \mathrm{mg} / \mathrm{ml}$ of the extract were prepared by serial dilutions in double strength Mueller Hinton broth medium for the bacterial isolates while concentrations for the determination of the minimum inhibitory concentrations of the fungal isolates were serially diluted in Saboraud dextrose broth. Each tube was then inoculated with $100 \mu \mathrm{l}$ of each of the adjusted bacterial and fungal strains. Two blank Mueller Hinton broth tubes and two blank Saboraud dextrose broth tubes, with and without bacterial and fungal inoculation, were used as the growth and sterility controls. The bacteria containing tubes were incubated at $37^{\circ} \mathrm{C}$ for $24 \mathrm{~h}$. The fungal containing tubes were incubated at $27^{\circ} \mathrm{C}$ for $72-96 \mathrm{~h}$. After the incubation period, the tubes were observed for the MICs by checking the concentration of the first tube in the series of tubes that showed no visible trace of growth. The first tubes in the series with no visible growth after the incubation period were taken as the MICs.

\section{Determination of minimum bactericidal concentrations (MBC)}

Since the clinical occurrences of tolerance usually necessitate bactericidal testing, the MBC was determined by sampling all the macroscopically clear tubes and the first turbid tube in the MIC series. Before being sampled, the tubes were gently mixed by flushing them with a sterile pipette, and a $100 \mu \mathrm{l}$ aliquot was removed. Each aliquot of the bacterial isolates was placed on a single antibiotic-free nutrient agar plate in a single streak down the centre of the plate and Saboraud dextrose agar was used for the fungal isolates, in accordance with the method of Shanholtzer et al. (1984). The samples were allowed to be absorbed into the agar until the plate surface appeared dry (after $30 \mathrm{~min}$ ). The aliquot was then spread over the plate by making a lawn of the bacterial and fungal culture with sterile cotton swab. In many studies on microbial susceptibility, this subculturing method has been found satisfactory in eliminating the problem of antimicrobial agent carryover from the $100 \mu \mathrm{l}$ subcultured volume (Bamberger et al., 1986; Moody et al., 1987; Fasching et al., 1990). The growth and sterility controls were sampled in the same manner. The MBC determining lawned plates were incubated for $24 \mathrm{~h}$ at $37^{\circ} \mathrm{C}$ for bacterial isolates and $27^{\circ} \mathrm{C}$ for $72-96 \mathrm{~h}$ for the fungal isolates. After the incubation periods, the lowest concentrations of the extract that did not produce any bacterial or fungal growth on the solid medium were regarded as the $\mathrm{MBC}$ and minimum fungicidal concentration (MFC) values for this extract (Irkin and Korukluoglu, 2007). This observation was matched with the MIC test tube that did not show evidence of growth after $48 \mathrm{~h}$ of incubation.

\section{Determination of mechanisms of antibiosis (bactericidal or bacteriostatic)}

The mechanism of antibiosis of the extract was calculated using the ratio of $\mathrm{MBC} / \mathrm{MIC}$ or MFC/MIC or $\mathrm{MIC}_{\text {index }}$ as described by Shanmughapriya et al. (2008) to elucidate whether the observed antibacterial effects were bactericidal or bacteriostatic. When the ratio of $\mathrm{MBC} / \mathrm{MIC}$ or $\mathrm{MFC} / \mathrm{MIC}$ was $\leq 2.0$, the extract was considered bactericidal/fungicidal or otherwise bacteriostatic/fungistatic. If the ratio is $\geq 16.0$, the extract was considered ineffective.

In this study, Gas Chromatography-Mass Spectrometry (GC-MS) analysis was used to identify the bioactive compounds of pharmaceutical importance in methanol stem back extract of $T$. madagascriense and the phytoconstituents in the extract is as shown in Table 1. The chromatogram indicating different phytoconstituents of methanol extract is shown in Figure 1. 
TABLE 1: Phytoconstituents of the methanol stem bark extract of T. madagascriense

\begin{tabular}{|c|c|c|c|c|c|}
\hline PEAK & $\begin{array}{l}\text { RETENTION } \\
\text { TIME }\end{array}$ & AREA \% & COMPOUND & QUALITY & ACTIVITY \\
\hline 1 & 3.401 & 0.69 & Dimethylamine & 53 & Antitumor \\
\hline 2 & 4.339 & 0.82 & 1H-Imidazole & 35 & Antifungal \\
\hline 3 & 4.951 & 1.83 & 2 - Furanmethanol & 64 & Hepatoprotective and Cytotoxic \\
\hline 4 & 6.031 & 0.79 & Dihydroxyacetone & 40 & Antioxidant and Anti-proliferative \\
\hline 5 & 6.060 & 0.63 & Dihydroxyacetone & 40 & Antioxidant and Anti-proliferative \\
\hline 6 & 9.153 & 0.67 & N- (n- Propyl) Acetamide & 46 & Anticancer, Anti-inflammatory \\
\hline 7 & 11.764 & 1.66 & Acetamide & 27 & Anticancer and Anti-inflammatory \\
\hline 8 & 12.453 & 0.76 & Cyclohexanol & 27 & Anticancer and Antidepres sant \\
\hline 9 & 12.850 & 0.63 & Methyl 2 -furoate & 52 & Anti-protozoal and Anti-inflammatory \\
\hline 10 & 13.147 & 6.01 & 3 - Methyl - 2 - Furoic acid & 50 & Cytotoxic and antitumor \\
\hline 11 & 3.901 & 8.96 & 4 -Chlorolysine & 53 & Analgesic and antiarrhythmic \\
\hline 12 & 14.720 & 0.82 & Ethanamine & 42 & Antimicrobial \\
\hline 13 & 14.940 & 9.45 & $4 \mathrm{H}-$ Pyran - 4 - one & 91 & $\begin{array}{l}\text { Antifungal, Anti-diabetic, Antioxidant, Antibacterial and Anti- } \\
\text { inflammatory }\end{array}$ \\
\hline 14 & 15.628 & 0.97 & $2(3 \mathrm{H})$ - Furanone & 64 & $\begin{array}{l}\text { Anti-inflammatory, Analgesic, Antiviral Anticonvuls ant, Cytotoxic } \\
\text { Antibacterial, and Antioxidant }\end{array}$ \\
\hline 15 & 16.368 & 1.15 & Ethanedial & 46 & $\begin{array}{l}\text { Antifungal, Anti-diabetic, Antioxidant, Antibacterial and Anti- } \\
\text { inflammatory }\end{array}$ \\
\hline 16 & 16.584 & 0.92 & $2(1 \mathrm{H})$ - Pyridinone & 81 & Antitumor, Anti-inflammatory, Antibacterial and Anti-fibrotic \\
\hline 17 & 17.070 & 1.44 & Catechol & 64 & $\begin{array}{l}\text { Antioxidant, Anti-platelet, Antibacterial, Anti-helmithic and } \\
\text { Antifungal }\end{array}$ \\
\hline 18 & 17.504 & 1.80 & Catecholborane & 49 & $\begin{array}{l}\text { Antibacterial, Antifungal, Anti-HIV, Analgesic, Antidepres sant, } \\
\text { Anticonvuls ant, Anti-diabetes, Antitumor, Anti-tubercular, } \\
\text { Antioxidant and Anti-inflammatory }\end{array}$ \\
\hline 19 & 17.765 & 12.26 & 5 - Hydroxymethylfurfural & 96 & $\begin{array}{l}\text { Antioxidant, Anti-proliferative, Antibacterial, Antifungal and } \\
\text { Hepatoprotective }\end{array}$ \\
\hline 20 & 18.168 & 1.37 & Hexanoic acid & 38 & Antifungal \\
\hline 21 & 19.634 & 4.82 & Indole & 95 & Anti-inflammatory, Antipyretic \\
\hline 22 & 19.836 & 0.69 & $\begin{array}{l}\text { N-Dimethylaminomethyl - } \\
\text { N-methylform amide }\end{array}$ & 38 & Anti-inflammatory, Antiviral and Anti-malarial \\
\hline 23 & 20.210 & 3.38 & Ethanone & 46 & $\begin{array}{l}\text { Antioxidant, Antiepileptic, Anticonvulsant, Anti-inflammatory, } \\
\text { Anticoagulant, Antiplasmodial and Antimalarial }\end{array}$ \\
\hline 24 & 21.296 & 3.10 & Phenol & 96 & $\begin{array}{l}\text { Antioxidant, Detoxifying agent, Antibacterial, Anti-inflammatory } \\
\text { and Antifungal }\end{array}$ \\
\hline 25 & 21.439 & 0.90 & Hexane & 18 & Antibacterial and Antifungal \\
\hline 26 & 22.596 & 2.36 & Vanillin & 90 & Antioxidant, Antidepress ant and Anti-inflammatory \\
\hline 27 & 22.685 & 7.62 & 1,4 - benzenediol & 94 & Antioxidant, Antibacterial and Antifungal \\
\hline 28 & 23.439 & 0.89 & Pyrrolidinium & 43 & Anti-bacteria \\
\hline 29 & 23.528 & 3.88 & Phenol & 95 & $\begin{array}{l}\text { Antioxidant, Detoxifying agent, Antibacterial, Anti-inflammatory } \\
\text { and Antifungal }\end{array}$ \\
\hline 30 & 24.816 & 0.86 & Benzonitrile & 41 & $\begin{array}{l}\text { Antimicrobial, Anti-tubercular, antifungal, Antihistamine, } \\
\text { Analgesic, Anti-helmintic and Antipsychotic }\end{array}$ \\
\hline 31 & 25.309 & 1.61 & Acetaldehyde semicarbazone & 50 & $\begin{array}{l}\text { Antifungal, Antibacterial, Antimalaria, Antiviral, Anticancer and } \\
\text { Anticonvulsant }\end{array}$ \\
\hline 32 & 25.742 & 0.77 & Benzoic acid & 46 & Antimicrobial \\
\hline 33 & 26.122 & 2.02 & Homovanillyl alcohol & 95 & Antioxidant and Antiplatelet \\
\hline 34 & 26.413 & 0.67 & Ethanone & 50 & $\begin{array}{l}\text { Antioxidant, Antiepileptic, Anticonvulsant, Anti-inflammatory, } \\
\text { Anti-malaria, Anti-plasmodial and Anticoagulant }\end{array}$ \\
\hline 35 & 27.374 & 1.07 & Silane & 58 & Antioxidant and Antimicrobial \\
\hline 36 & 28.104 & 3.28 & Phenol & 95 & $\begin{array}{l}\text { Antioxidant, Detoxifying agent, Antibacterial, Anti-inflammatory } \\
\text { and Antifungal }\end{array}$ \\
\hline 37 & 28.953 & 0.71 & $7(3 \mathrm{H}, 7 \mathrm{H})-$ dione & 35 & Antioxidant, Anticancer, Antibacterial and Antifungal \\
\hline 38 & 31.018 & 1.04 & $\begin{array}{l}4-((1 \mathrm{E})-3-\text { Hydroxy }-1- \\
\text { propenyl })-2 \text {-methoxyphenol }\end{array}$ & 97 & $\begin{array}{l}\text { Antimicrobial, Anti-tubercular, Anti-inflammatory, Analgesic and } \\
\text { Anticonvulsant }\end{array}$ \\
\hline 39 & 35.025 & 0.91 & Hexadecanoic acid & 95 & $\begin{array}{l}\text { Antifungal, Antibacterial, Antioxidant, Anti-androgenic, } \\
\text { Nematicide, Haemolytic and Hypocholesterolemic }\end{array}$ \\
\hline 40 & 45.447 & 0.61 & 2,6 - octadiene & 35 & Antiplatelet \\
\hline 41 & 46.296 & 0.63 & $\begin{array}{c}\text { Tricyclo }[4.3 .2 .1(3,8)] \\
\text { undecane - } 1 \text { - carboxylic acid }\end{array}$ & 50 & Antiplatelet \\
\hline 42 & 47.085 & 0.93 & Lanosterol & 49 & Antifungal and suppres ses hepatic cholesterol \\
\hline 43 & 47.204 & 1.30 & Azulene & 50 & Anti-inflammatory, Antibacterial, Antifungal and Antioxidant \\
\hline 44 & 47.952 & 1.09 & Benzocyclododecene & 47 & $\begin{array}{l}\text { Anti-inflammatory, Antimicrobial, Antitumor, Antiviral, Anti- } \\
\text { hepatitis, and Anticoagulant }\end{array}$ \\
\hline 45 & 51.679 & 1.23 & $3(2 \mathrm{H})-$ dione & 55 & Antioxidant and Anticancer \\
\hline
\end{tabular}




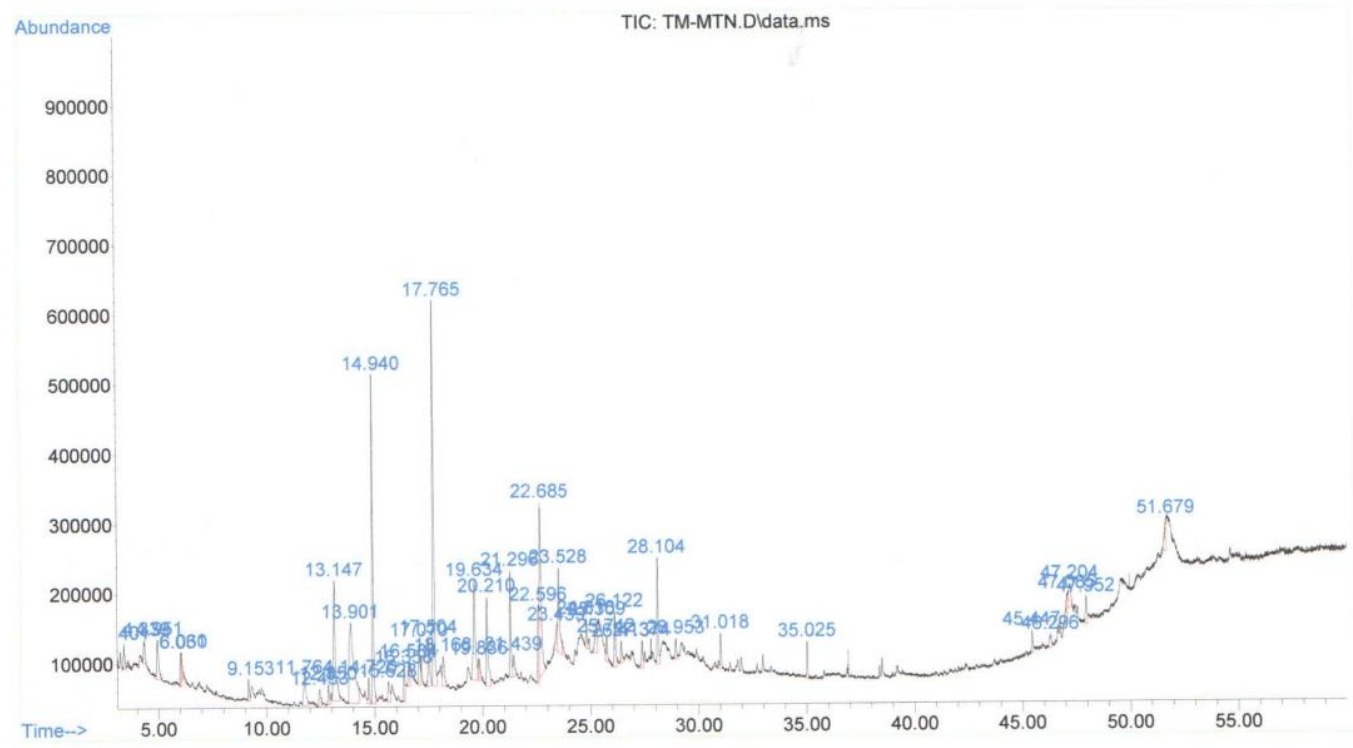

FIG. 1: The chromatograms of phytoconstituents in methanol stem bark extract

Forty five phytoconstituents were identified as being present in the methanol stem bark extract of this plant. Some of these include $2(1 \mathrm{H})-$ pyridinone, catechol, 1H-imidazole, dihydroxyacetone, N- (npropyl) acetamide, cyclohexane, catecholborane, 5 hydroxymethylfurfural, indole, phenol, hexane, vanillin, pyrrolidinium, $4-((1 \mathrm{E})-3-$ hydroxy $-1-$ propenyl) - 2 -methoxyphenol, lanosterol and benzocyclododecene which are of various therapeutic importance. Comparing the mass spectra of the identified compounds in the extract with those in the GC-MS library and determining the mass spectra to identify some of the most significant compounds of therapeutic importance during each retention time showed the presence of ethyl iso-allocholate, paromomycin, indole, phenol and $\alpha$-Dglucopyranoside in the methanol extract.
The methanolic extract of $T$. madagascriense stem bark obtained showed concentration dependent antibacterial activity against $E$. faecalis ATCC 29212, K. pneumoniae ATCC 10031, B. subtilis KZN, S. aureus ATCC 6538, B. cereus ATCC 10702, $P$. aeruginosa ATCC 19582, E. coli ATCC 25922, $P$. vulgaris, CSIR 0030, E. cloacae ATCC 13047 and $S$. sonnei ATCC 29930, $E$. faecalis KZN, $K$. pneumoniae $\mathrm{KpFa}$, S. aureus $\mathrm{SaFa}$, E. coli $\mathrm{EcFa}$, and $P$. aeruginosa $\mathrm{PmFa}$. As the concentration increases, the activity increases. At the lowest concentration of $25 \mathrm{mg} / \mathrm{ml}, 0.1 \mathrm{ml}$ of the extract produced inhibition zones in all the isolates. The inhibition zones ranged between 14 and $18 \pm 1.0 \mathrm{~mm}$. At the highest concentration of $100 \mathrm{mg} / \mathrm{ml}, 0.1 \mathrm{ml}$ of the extract produced inhibition zones ranging between 18 and 28 $\pm 1.0 \mathrm{~mm}$ as indicated in Table 2 .

TABLE 2: Antibacterial effects of methanol stem bark extract of T. madagascriense by agar diffusion assay

\begin{tabular}{|c|c|c|c|c|}
\hline \multirow[b]{2}{*}{ Name of Organism } & \multicolumn{4}{|c|}{$\begin{array}{l}\text { Inhibition zones produced by } 0.1 \mathrm{ml} \text { of } \\
\text { concentrations of methanol extract }( \pm 1.0 \mathrm{~mm})\end{array}$} \\
\hline & $100 \mathrm{mg} / \mathrm{ml}$ & $75 \mathrm{mg} / \mathrm{ml}$ & $50 \mathrm{mg} / \mathrm{ml}$ & $25 \mathrm{mg} / \mathrm{ml}$ \\
\hline Enterococcus faecalis ATCC 29212 & $20 \pm 1.00$ & $18 \pm 1.53$ & $16 \pm 0.00$ & $15 \pm 0.58$ \\
\hline Klebsiella pneumoniae ATCC 10031 & $20 \pm 0.58$ & $18 \pm 0.58$ & $16 \pm 0.0$ & $15 \pm 0.00$ \\
\hline Bacillus subtilis $\mathrm{KZN}$ & $22 \pm 1.53$ & $21 \pm 1.00$ & $20 \pm 1.00$ & $18 \pm 0.58$ \\
\hline Staphylococcus aureus ATCC 6538 & $21 \pm 0.58$ & $18 \pm 0.00$ & $17 \pm 0.58$ & $15 \pm 0.00$ \\
\hline Bacillus cereus ATCC 10702 & $18 \pm 1.53$ & $17 \pm 1.00$ & $16 \pm 0.58$ & $15 \pm 0.00$ \\
\hline Pseudomonas aeruginosa ATCC 19582 & $18 \pm 0.00$ & $17 \pm 0.00$ & $15 \pm 0.58$ & $14 \pm 0.00$ \\
\hline Escherichia coli ATCC 25922 & $21 \pm 0.58$ & $20 \pm 0.00$ & $18 \pm 1.53$ & $16 \pm 1.00$ \\
\hline Enterobacter cloacae ATCC 13047 & $18 \pm 0.58$ & $17 \pm 0.58$ & $16 \pm 1.00$ & $15 \pm 1.00$ \\
\hline Enterococcus faecalis $\mathrm{KZN}$ & $20 \pm 1.53$ & $19 \pm 1.00$ & $17 \pm 0.58$ & $15 \pm 1.53$ \\
\hline Shigella sonnei ATC $\quad$ C 29930 & $19 \pm 1.00$ & $17 \pm 1.00$ & $16 \pm 0.58$ & $14 \pm 0.00$ \\
\hline Klebsiella pneumoniae $\mathrm{KpFa}$ & $21 \pm 0.00$ & $19 \pm 0.58$ & $18 \pm 1.00$ & $15 \pm 0.00$ \\
\hline Staphylococcus aureus $\mathrm{SaFa}$ & $23 \pm 0.00$ & $21 \pm 1.53$ & $18 \pm 0.00$ & $15 \pm 1.00$ \\
\hline Escherichia coli $\mathrm{EcFa}$ & $21 \pm 0.58$ & $18 \pm 1.53$ & $15 \pm 0.58$ & $14 \pm 0.00$ \\
\hline Proteus vulgaris CSIR 0030 & $23 \pm 0.58$ & $20 \pm 1.00$ & $17 \pm 0.00$ & $15 \pm 0.00$ \\
\hline Pseudomonas aeruginosa $\mathrm{PmFa}$ & $28 \pm 0.58$ & $24 \pm 1.53$ & $20 \pm 0.58$ & $18 \pm 0.58$ \\
\hline
\end{tabular}


The inhibitory and bactericidal activities of the extract of $T$. madagascriense against the different test bacterial strains are presented in Table 3 with the minimum inhibitory concentrations (MICs) ranging between 1.25 and $5 \mathrm{mg} / \mathrm{ml}$ while the MBCs ranged between 2.5 and $10 \mathrm{mg} / \mathrm{ml}$. With exception of $\mathrm{MIC}_{\text {index }}$ of $K$. pneumoniae ATCC 10031 which was equal to 4 , the $\mathrm{MIC}_{\text {index }}$ of other isolates ranged between 1 and 2. K. pneumoniae ATCC 10031 and $P$. vulgaris CSIR 0030 had the highest MICs of 1.25 $\mathrm{mg} / \mathrm{ml}$. These were followed by E. faecalis ATCC 29212, B. subtilis KZN and P. vulgaris CSIR 0030 with MICs of $2.5 \mathrm{mg} / \mathrm{ml}$. While E. coli ATCC 25922,
E. cloacae ATCC 13047, E. faecalis KZN, S. sonnei ATCC 29930, K. pneumoniae $\mathrm{KpFa}, S$. aureus $\mathrm{SaFa}$, E. coli $\mathrm{EcFa}$ and $P$. aeruginosa $\mathrm{PmFa}$ had the least MICs of $5.0 \mathrm{mg} / \mathrm{ml}$. E. faecalis KZN, B. subtilis KZN and $P$. vulgaris CSIR 0030 had the highest MBCs of $2.5 \mathrm{mg} / \mathrm{ml}$. These were followed by $K$. pneumoniae ATCC, $S$. aureus ATCC, B. cereus ATCC, $P$. aeruginosa ATCC, $S$. aureus $\mathrm{SaFa}$ and $P$. aeruginosa PmFa having 5.0 MBCs while E. coli ATCC, E. cloacae ATCC, E. faecalis KZN, K. pneumoniae $\mathrm{KpFa}$, and E. coli $\mathrm{EcFa}$ had the least MBCs of 10 $\mathrm{mg} / \mathrm{ml}$.

TABLE 3: Minimum inhibitory \& minimum bactericidal concentrations of methanol extract of T. madagascriense against different bacterial pathogens in dysentery

Inhibition and bactericidal concentrations of the methanolic extract

\begin{tabular}{lcccc}
\hline Name of Organisms & MIC $(\mathrm{mg} / \mathrm{ml})$ & MBC $(\mathrm{mg} / \mathrm{ml})$ & MBC / MIC & Remarks \\
\hline Enterococcus faecalis ATCC 29212 & 2.5 & 2.5 & 1 & Bactericidal \\
Klebsiella pneumoniae ATCC 10031 & 1.3 & 2.5 & 2 & Bactericidal \\
Bacillus subtilis KZN & 2.5 & 2.5 & 1 & Bactericidal \\
Staphylococcus aureus ATCC 6538 & 2.5 & 5.0 & 2 & Bactericidal \\
Bacillus cereus ATCC 10702 & 2.5 & 5.0 & 2 & Bactericidal \\
Pseudomonas aeruginosa ATCC 19582 & 2.5 & 5.0 & 2 & Bactericidal \\
Escherichia coli ATCC 25922 & 5.0 & 10.0 & 2 & Bactericidal \\
Enterobacter cloacae ATCC 13047 & 5.0 & 10.0 & 2 & Bactericidal \\
Enterococcus faecalis KZN & 5.0 & 10.0 & 2 & Bactericidal \\
Shigella sonnei ATCC 29930 & 5.0 & 10.0 & 2 & Bactericidal \\
Klebsiella pneumoniae KpFa & 5.0 & 10.0 & 2 & Bactericidal \\
Staphylococcus aureus SaFa & 5.0 & 5.0 & 1 & Bactericidal \\
Escherichia coli EcFa & 5.0 & 10.0 & 2 & Bactericidal \\
Proteus vulgaris CSIR 0030 & 1.3 & 2.5 & 2 & Bactericidal \\
Pseudomonas aeruginosa PmFa & 5.0 & 5.0 & 1 & Bactericidal \\
\hline
\end{tabular}

The methanolic extract of $T$. madagascriense stem bark obtained showed antifungal activity against $C$. albicans CA4, C. tropicalis CT4, C. albicans CA15, C. albicans CA6 and C. albicans CA23 as shown in Table 4. The antifungal activity of the methanolic extract is concentration dependent. As the concentration increases, the activity increases. At the lowest concentration all fungal specimen were susceptible with the exception of $C$. albicans CA15. However, fungal isolates inhibited at the different concentrations had inhibition zones ranging between 17 and $25 \pm 1.0 \mathrm{~mm}$ at the highest concentration of $100 \mathrm{mg} / \mathrm{ml}$ and between 12 and $19 \pm 1.0 \mathrm{~mm}$ at the lowest concentration of $25 \mathrm{mg} / \mathrm{ml}$.

TABLE 4: Antifungal effects of methanol extract of T. madagascriense by agar diffusion assay

\begin{tabular}{|c|c|c|c|c|}
\hline \multirow[b]{2}{*}{ Name of Organism } & \multicolumn{4}{|c|}{$\begin{array}{l}\text { Inhibition zones produced by } 100 \quad \mu \mathrm{l} \text { of different } \\
\text { concentrations of methanol extract }( \pm 1.0 \mathrm{~mm})\end{array}$} \\
\hline & $100 \mathrm{mg} / \mathrm{ml}$ & $75 \mathrm{mg} / \mathrm{ml}$ & $50 \mathrm{mg} / \mathrm{ml}$ & $25 \mathrm{mg} / \mathrm{ml}$ \\
\hline Candida albicans CA4 & 25 & 23 & 20 & 18 \\
\hline Candida tropicalis CT4 & 23 & 22 & 20 & 18 \\
\hline Candida albicans CA15 & 17 & 15 & 14 & 6 \\
\hline Candida albicans CA6 & 18 & 15 & 14 & 12 \\
\hline Candida albicans CA23 & 24 & 23 & 20 & 19 \\
\hline
\end{tabular}


The minimum inhibitory concentrations (MICs) for the fungal isolates are shown in Table 5. The MICs of the fungal isolates ranged between 0.098 and 12.5 $\mathrm{mg} / \mathrm{ml}$ while the MFCs ranged between 0.781 and $<25 \mathrm{mg} / \mathrm{ml}$ for the methanolic extract of $T$. madagascriense. C. albicans CA23 had the highest MIC of $0.098 \mathrm{mg} / \mathrm{ml}$, followed by $C$. albicans CA 4 with MIC of $0.391 \mathrm{mg} / \mathrm{ml}$ and $C$. albicans CA6 with MIC of $1.562 \mathrm{mg} / \mathrm{ml}$. C. tropicalis CT4 and $C$. albicans CA15 had the least MICs of $12.5 \mathrm{mg} / \mathrm{ml}$. $C$. tropicalis CT4 and C. albicans CA15 had the least MFCs of 25 and $<25 \mathrm{mg} / \mathrm{ml}$ while $C$. albicans CA23 had the highest MFC of $0.781 \mathrm{mg} / \mathrm{ml}$. The $\mathrm{MIC}_{\text {index }}$ was equal to 2 with the exception of $C$. albicans CA4, C. tropicalis CT4 and C. albicans CA23 for which MIC index was 15.985, <2 and 7.969 respectively.

TABLE 5: Minimum inhibitory \& minimum fungicidal concentrations of the methanolic extract of $T$. madagascriense against different fungal pathogens

\section{Inhibition and fungicidal concentrations of the} methanolic extract

\begin{tabular}{|c|c|c|c|c|}
\hline Name of Organisms & MIC (mg/ml) & MFC (mg/ml) & MFC/MIC & Remark \\
\hline Candida albicans CA4 & 0.391 & 6.25 & 15.985 & Ineffective \\
\hline Candida tropicalis CT4 & 12.5 & $<25$ & $<2$ & Fungicidal \\
\hline Candida albicans CA15 & 12.5 & 25 & 2 & Fungicidal \\
\hline Candida albicans CA6 & 1.562 & 3.125 & 2 & Fungicidal \\
\hline Candida albicans CA23 & 0.098 & 0.781 & 7.969 & Fungicidal \\
\hline
\end{tabular}

The plant used in this study, T. madagascriense, has been ethnobotanically indicated to be used in the treatment of various diseases in traditional medicine. The stem bark and the leaves are the preferred part for the preparation of traditional medicine (Ampa et al., 2013; Teke et al., 2010). The GC-MS analysis of the methanol stem bark extract of $T$. madagascriense indicated the presence of various phytochemicals, in this study, with antimicrobial, antiviral, antitumor, anticancer, anti-inflammatory, antidotal, antidepressant, anti-proliferative, antioxidant, anticonvultant, analgestic, cytotoxic, antifibrotic, antitubercular, antidiabetic, antiplatelet, antipyretic, antiplasmodial, hypercholesterolemic and anticoagulant activities. The antimicrobial activities of the extract recorded in this study can be attributed to paromomycin, indole, ethyl iso-allocholate, phenol and $\alpha$-D-glucopyranoside which were part of the most significant therapeutic compounds identified during each retention time.

Paramomycin, indole, ethyl iso-allocholate and phenol have been reported to possess strong antimicrobial properties (Sundar and Chang, 1993; Meyer et al., 1999; Huang et al., 2011). Paramomycin which was originally isolated from the fermentation of Streptomyces in 1956 ( $\mathrm{Lu}$ et al.,
1997) has been reported to possess broad spectrum activity against Gram-negative and Gram-positive bacteria (Stead, 2000) such as E. coli, S. aureus, S. pyogenes, $P$. vulgaris and K. Pneumoniae (Francois et al., 2004) as well as some protozoa and cestodes (Davidson et al., 2009). In humans, paromomycin has been used to treat leishmaniasis, cryptosporidiosis, and amebiasis (Flanigan et al., 1996; Fahey, 2003; Murray et al., 2005). Its presence in this plant is of significance. This is the first time it will be identified in a medicinal plant as it has not being reportedly found in medicinal plants prior now as evident from literature search. Indole which has been isolated from the stem bark ethanol extract of Aspidosperma ramiflorum (Tanaka et al., 2006), stem bark methanol extract of Aspidosperma olivaceum (Chierrito et al., 2014) and stem bark ethanol extract of Winchia calophylla (Zhu et al., 2005) has been reported to have antibacterial effects against $S$. aureus, E. coli and $P$. aeruginosa (Medeiros et al., 2011). Ethyl isoallocholate which have been isolated from the ethanol extract of Podophyllum hexandrum rhizome (Li et al., 2012), ethanol extract of Kirganelia reticulate aerial parts (Muthulakshmi et al., 2012) and ethanol extract of Feronia elephantum stem bark (Muthulakshmi et al., 2012 Sudha et al., 2013) have been reported to possess antimicrobial activities 
(Singariya et al., 2012). Phenol has been isolated from the methanolic extract of Ficus religiosa stem bark (Manorenjitha et al., 2013), and methanol extract of Psidium guajava root bark (Velmurugan et al., 2012). Phenol bactericidal actions at high concentration include penetration and disruption of cell wall and precipitation of cell proteins while at low concentrations it causes bacteria death by inactivation of essential enzyme systems and leakage of essential metabolites from the cell wall (Prindle, 1983). It has been reported to possess antimicrobial activities against $E$. coli, $S$. aureus, $P$. aerugimosa and $C$. albicans (Cueva et al., 2010). $\alpha$-Dglucopyranoside, a glucopyranose which has been isolated from the aqueous extract of Tulbaghia violacea (Lyantagaye et al., 2013), has been reported to possess antimicrobial activity against $B$. cereus, $S$. sonnei, S. aureus, B. subtilis, S. typhi and Macrophomina phaseolina (Kawsar et al., 2014). The antimicrobial activities of $T$. madagascriense could, therefore, be attributed to the presence of these phytochemicals in its methanol stem bark extract.

Previous study on the methanol stem bark extract of this plant indicated the isolation of isoliquiritigenin, a flavonoid and vanillin (Teke et al., 2011), trilepisflavan, trilepisuimic acid, dihydrokaempferol and 8-C-glucopyranosylapigenin (Ango et al., 2012). These phytoconstituents, except vanillin which was indicated in the GC report of the methanol extract, were all not identified in the GC-MS analysis while $\alpha$-D-glucopyranoside, which is a glucopyranose like 8-C-glucopyranosylapigenin, was identified in the mass spectrogram of the methanol extract of $T$. madagascriense in this study. This variation could be as a result of differences in geographical locations, maturity and time of harvesting as well as methods of identification while the former was carried out on plant harvested in Dschang, Cameroun.

Anti-diarrheal and anti-dysenteric activities of medicinal plants have been attributed to the presence of tannins, alkaloids, saponins, flavonoids, steroids and terpenoids (Havagiray et al., 2004). Alkaloids, flavonoids, tannins and saponins were previously detected in the phytochemical analysis of the methanol extract of this plant (Teke et al., 2010), this explains the activity of the plant extract against diarrhoea and dysentery causing organisms used in this study. All selected bacterial strains used in this study were susceptible to the methanol extract of the plant. This may be due to the extraction ability of methanol as it is known to be a junk extractor and whose plant extracts have been observed to be very effective against most bacteria strains. It could also be due to the amount of phytochemicals being extracted. The degree of susceptibility did not depend on the fungi and bacteria class as both Gram-positive and Gram-negative strains were susceptible to the methanol extract. This indicated that the plant extract has broad spectrum of antimicrobial capabilities. $E$. coli EcFA, E. faecalis KZN, $K$. pneumoniae and $P$. aeruginosa, though multidrug resistant strains were susceptible to all concentrations of this extract. The ability of this extract to inhibit the growth of the multidrug resistant clinical isolates showed the importance of this plant in treating multi-drug resistant infections and nosocomial infections. Iinuma et al. 1994, Kim et al. 1995, Aburjai et al. 2001 and Darwish et al. 2002 indicated that many plants are known for their action as resistancemodifying agents.

Using turbidity as a measure of growth, the MIC and MBC showed that the methanol extract of this plant was both bacteriostatic and bactericidal. The MIC and $\mathrm{MBC}$ values are often close or hooked values, however, MBC values can either be the same or higher than the corresponding MIC values (Olajuyigbe and Afolayan, 2011). The $\mathrm{MIC}_{\text {index }}$ showed that the methanol extract was bacteriostatic at lower concentration and bactericidal at higher concentration. The MICs of the methanol extract of Thuja orientalis was higher $(2.00 \mathrm{mg} / \mathrm{ml}$ and 1 $\mathrm{mg} / \mathrm{ml}$ ) than the methanol extract of $T$. madagascriense against $P$. aeruginosa and $S$. aureus, $2.5 \mathrm{mg} / \mathrm{ml}$ and $2.5 \mathrm{mg} / \mathrm{ml}$ respectively, while $T$. madagascriense MIC was higher against $K$. pneumonia $(1.25 \mathrm{mg} / \mathrm{ml})$ than that of Thuja orientalis $(1.5 \mathrm{mg} / \mathrm{ml})$ (Duhan et al., 2013). This shows that methanol extract of $T$. madagascriense could be more effective than those of other medicinal plants in the treatment of infections caused by the susceptible bacterial isolates.

All the fungal strains used in this study were susceptible to the extract of this plant at varied concentration and indicated that the extract has strong antifungal properties. The MIC and MFC showed that the methanol extract of the plant was both fungistatic and fungicidal. The $\mathrm{MIC}_{\text {index }}$ showed that the extract was fungistatic at lower concentration and fungicidal at higher concentration. The antifungal (anticandidiasis) activities of the methanol extract of T. madagascariense $(0.098-12.5 \mathrm{mg} / \mathrm{ml})$ were higher than that of the methanol extract of Lupinus varius $(32 \mathrm{mg} / \mathrm{ml})$ against Candida albicans. The antifungal (anticandidiasis) activities of the extract of T. madagascariense producing inhibition zones ranging between 17 and $25 \pm 1.0 \mathrm{~mm}$ was higher than that of the methanol extract of Ecbalium elaterium $(16 \pm 1.0 \mathrm{~mm})$ and Mandragora autumnalis $(18.7 \pm$ $1.0 \mathrm{~mm}$ ) at $100 \mathrm{mg} / \mathrm{ml}$ of each extract (Obeidat et al., 2012). 
In conclusion, this study identifying phytoconstituents of therapeutic importance and antimicrobial activities of $T$. madagascriense, used in the treatment of various ailments by the local populations, indicated the therapeutic potentials of this plant scientifically and justify its ethnomedicinal use in the treatment of diarrhoea and dysentery. Of the bioactive compounds identified through GC-MS analysis, the mass spectrogram showed the presence of paramomycin not yet reportedly present in any medicinal plant. Further research on the isolation and characterization of these bioactive compounds of economic, pharmaceutical and therapeutic values from $T$. madagascriense is ongoing in our research laboratory.

\section{CONFLICTS OF INTEREST}

The authors declared no conflict of interest.

\section{ACKNOWLEDGEMENT}

The authors hereby acknowledge the support of the Babcock University Research Grant number (BU/RIIC/2016/03).

\section{REFERENCES}

1. Aburjai, T.; Darwish, R.M.; Al-Khalil, S.; Mahafza, A.; AlAbbadi, A. (2001) Screening of antibiotic resistant inhibitors from local plant materials against two different strains of Pseudomonas aeruginosa. J. Ethnopharmacol., p. 39 - 44, v. 76, 2001 .

2. Ahvazia, M,; Khalighi-Sigaroodib, F.; Charkhchiyanc, M.M.; Mojabd, F.; Mozaffariane, V.A.; Zakerif, H. Introduction of Medicinal Plants Species with the Most Traditional Usage in Alamut Region. Iranian J. Pharm. Res., p. 185 - 194, v. 11(1), 2012.

3. Alp, S. Bacterial resistance to antiseptics and disinfectants. Mikrobiyoloji Bulteni, p. 155-161, 41, 2007.

4. Ampa, R.; Ahomboi, G.; Nguimbii, E.; Diatewa, M.; Dimo, T.; Ouambai, M.; Abena, A.A. Evaluation of hypoglycemic, antihyperglycemic and antidiabetic properties of Trilepisium madagascariense D.C. Leeuwenberg (Moraceae). J. Biotechnol. Pharmaceut. Res., p. 48 - 53, 4(3), 2013.

5. Ango, P.Y.; Kapche, D.W.; Kuete, V.; Ngadjui, B.T.; Bezabih, M.; Abegaz, B.M.; Chemical constituents of Trilepisium madagascariense (Moraceae) and their antimicrobial activity. Phytochem. Lett., p. $524-528$, v. 5(3), 2012.

6. Balunas, M.J.; Kinghorn, A.D. Drug discovery from medicinal plants. Life Sci., p. 431, 78, 2005.

7. Bamberger, D.M.; Peterson, L.R.; Gerding, D.N.; Moody, J.A.; Fasching, C.E. Ciprofloxacin, azlocillin, ceftizoxime, and amikacin alone and in combination against Gram negative bacilli in an infected chamber model. J. Antimicrob. Chemother., p. 51-63, v. 18, 1986.

8. Bull, D. Gas chromatography mass spectrometry. Bristol Biogeochemistry Research Centre (C) 2002 - 2015 University of Bristol, 2008.

9. Cheesbrough, M. () Medical Laboratory Manual for Tropical Countries, ELBS ed; Tropical health technology publications and Butterworth-Heinemann Ltd: Cambridge, UK, p. 2-392, v. 2, 2002.

10. Cheesbrough, M. District Laboratory Practice in Tropical Countries. Part 2: Cambridge University press, Cambridge, p. 62-69, 2009

11. Chierrito, T.P.; Aguiar, A,C.; Andrade, I,M.; Ceravolo, I.P.; Goncalves, R,A.; Oliveira, A.J.; Krettli, A.U. Anti-malarial activity of indole alkaloids isolated from Aspidosperma olivaceum. Malaria J.; p. 142, v. 13, 2014.

12. Chowdhury, A.N.; Ashrafuzzaman, M.; Ali, H.; Liza, L.N.; Zinnah, M.A. Antimicrobial activity of some medicinal plants against multidrug resistant human pathogens. Adv. Biosci. Biotechnol., p. 1 - 24, v. 1(1), 2013.

13. Cock, I.; Setzer, W.N.; Ruebhart, K.D.; El Dahshan, O.A.; Tomczyk, M. An anti-diabetic and hypolipidemic effects from Azadirachta indica leaves. Afr. J. Biotechnol., p. 3084 3091, v. 8(13), 2009.

14. Cueva, C.; Moreno-Arribas, M.V.; Martin-Alvarez, P.J.; Bills, G.; Vicente, M.F.; Basilio, A.; Rivas, C.L.; Requena, T.; Rodriguez, J.M.; Bartolome, B. Antimicrobial activity of phenolic acids against commensal, probiotic and pathogenic bacteria. Res. Microbiol., p. 372 - 382, v. 161(5), 2010.

15. Darwish, R.M.; Aburjai, T.; Al-Khalil, S.; Mahafza, A.; AlAbbadi, A. (2002) Screening of antibiotic resistant inhibitors from local plant materials against two different strains of Staphylococcus aureus. J. Ethnopharmacol., p. 359 - 364, v. 79, 2002.

16. Davidson, R.N.; Den, B.M.; Ritmeijer, K. Paromomycin. Trans. Royal Soc. Trop. Med. Hyg., p. 653 - 660, v. 103(7), 2009.

17. Doughari, J.H. Phytochemicals: Extraction methods, basic structures and mode of action as potential chemotherapeutic agents. Intechnology,

DOI: 10.5772/26052, 2012.

18. Duhan, J.S.; Saharan, P.; Surekha Kumar, A. (2013) Antimicrobial potential of various fractions of Thuja orientalis. Afr. J. Microbiol. Res., p. 3179 - 3186, v. 7, 2013.

19. European Committee for Antimicrobial Susceptibility Testing (EUCAST) (2000) Determination of minimum inhibitory concentrations (MICs) of antibacterial agents by agar dilution. Clin. Microbiol. Infect., p. 509-515, v. 6, 2000.

20. Fahey, T. Cryptosporidiosis. Primary Care Update for OB/GYNS p, 75-80, v, 10, 2003.

21. Fasching, C.E.; Peterson, L.R.; Moody, J.A.; Sinn, L.M.; Gerding, D.N. Treatment evaluation of experimental staphylococcal infections comparing $\beta$-lactam, lipopeptide, and glycopeptide antimicrobial therapy. J. Lab. Clin. Med., p. 697-706, v. 116, 1990.

22. Flanigan, T.P.; Ramratnam, B.; Graeber, C.; Hellinger, J.; Smith, D.; Wheeler, D.; Hawley, P.; Heath-Chiozzi, M.; Ward, D.J.; Brummitt, C.; Turner, J. Prospective Trial of paromomycin for cryptosporidiosis in AIDS. Am, J, Med., p. 370 - 372, v. 100,1996

23. Forbes, B.A.; Sahm, D.F.; Weissfeld, A.S. Bailey and Scott's diagnostic microbiology. 12 ${ }^{\text {th }}$ ed. Mosby; p. 98-257, 2007.

24. Francois, B.; Szychowski, J.; Adhikari, S,S.; Pachamuthu, K.; Swayze, E.E.; Griffey, R.H.; Migawa, M.T. Antibacterial aminoglycosides with a modified mode of binding to the ribosomal-rna decoding site. Angewandte Chemie International Edition, p. 6735 - 6738, v. 43. 2004.

25. Geetha, T.S.; Geetha, N. Phytochemical Screening, Quantitative analysis of primary and secondary metabolites of Cymbopogan citratus (DC) stapf. leaves from Kodaikanal hills, Tamilnadu. Int. J. PharmTech. Res., p. 521 - 529, v. 6(2), 2014.

26. Gracelin, H.S.; Britto, A.J.; Kumar, B.J.R. Qualitative and quatitative analysis of phytochemicals in five Pteris species. Int. J. Pharm. Pharmaceut. Sci., p. 105 - 107, v. 5(1), 2013.

27. Harborne, J.B. Phytochemical Methods: A Guide to Modern Techniques of Plant Analysis, $2^{\text {nd }} \quad$ edn. Chapman and Hall, New York, 1984.

28. Havagiray, R.; Ramesh, C.; Sadhna, K. Study of antidiarrhoeal activity of Calotropis gigantean r.b.r. in experimental animals. J. Pharmaceut. Sci., p. 70 - 5, v. 7, 2004.

29. Holt, J.G.; Krieg, N.R.; Sneath, P.H.A.; Williams, S.T. Staphylococcus spp. In: Bergey's manual of determinative bacteriology, $9^{\text {th }}$ ed. Baltimore, MD: Williams \& Wilkiins; p. 544-51, 1994. 
30. Hossain, M.A.; Nagooru, M.R. (2011) Biochemical profiling and total flavonoids contents of leaves crude extract of endemic medicinal plant Corydyline terminalis L. Kunth,. Pharmacog. J., 25-30, v. 3, 2011.

31. Huang, C.B.; Alimova, Y.; Myers. T.M.; Ebersole, J.L. Short- and medium-chain fatty acids exhibit antimicrobial activity for oral microorganisms. Arch. of Oral Biol., p. $650-$ 654, v. 56(7), 2011.

32. Iinuma, M.; Tsuchiya, H.; Sato, M.; Yokoyama, J.; Ohyama, M.; Ohkawa, Y.; Tanaka, T.; Fujiwara, S.; Fujii T. Flavanones with potent antibacterial activity against methicillin-resistant Staphylococcus aureus. J. Pharm. Pharmacol., p. 892 - 895, v. 46, 1994

33. Irkin, R.; Korukluoglu, M. () Control of Aspergillus niger with garlic, onion and leek extracts. Afr. J. Biotechnol., p. 384-387, v. 6, 2007.

34. Iwaki, K.; Koya-Miyata, S.; Kohno, K.; Ushio, S.; Fukuda, S. Antimicrobial activity of Polygonum tintorium Lour. extract against oral pathogenic bacteria. Nat. Med., p. 72-79, v. 53, 2006.

35. Kar, A.; Dethi, A.; Ababa, A. Pharmacognosy and Phytochemistry, Nirali Prakashan, India, pp. 238-239, 2007.

36. Kawsar, S.M.; Faruk, O.; Ozeki, Y. Regioselective synthesis, characterization and antimicrobial activities of some new monosaccharide derivatives. Scientia Pharmaceut., p. $1-20$ v. 82(1), 2014.

37. Khan, A.; Rhaman, M.; Islam S. Antibacterial, antifungal and cytotoxic activities of tuberous roots of Amorphophallus campanulatus. Turkish J. Biol., p. 167-172, v. 31, 2007.

38. Kim, H.; Park, S.W.; Park, J.M.; Moon, K.H.; Lee, C.K. Screening and isolation of antibiotic resistant inhibitors from herb materials I -Resistant Inhibition of 21 Korean Plants. Nat. Prod. Sci., p. 50 - 54, v. 1, 1995.

39. Kuiate, J.K. Antidiarrheal, antimicrobial and antioxidant properties of two cameroonian medicinal plants: Trilepisium madagascariense DC. leeuwenberg (Moraceae) and Entada abyssinica (Mimosaceae). Jules-Roger et la paix: Publications scientifiques, 2011. http://jrkuiate.blog4ever.com/blog/index-318439.html Assessed 17/2/201.

40. Li, M.; Zhou, L.; Yang, D.; Li, T.; Li, W. Biochemical composition and antioxidant capacity of extracts from Podophyllum hexandrum rhizome. BMC Compl. Alt. Med., p. 263, v. 12, 2012

41. Listorti, J.A.; Doumani, F.M. Environmental health: Bridging the gaps. World Bank Publications: p. 372, 2001.

42. Lu, J.; Cwik, M.; Kanyok, T. () Determination of paromomycin in human plasma and urine by reversed-phase high-performance liquid chromatography using 2,4dinitrofluorobenzene derivatization. J. Chromatog. Biomed. Sci. Appl., p. 329 - 335, v. 695, 1997.

43. Lucantoni, L.; Yerbanga, R.S.; Pasqualini, G.L.L.; Esposito, F.; Habluetzel, A.; Transmission blocking activity of a standardized neem (Azadirachta Indica) seed extract on the rodent malaria parasite Plasmodium berghei in its vector Anopheles stephensi. Malaria J., p. 66-70, v9, 2010.

44. Lyantagaye, S.L. Characterization of the biochemical pathway of apoptosis induced by D-glucopyranoside derivatives from Tulbaghia violacea. Ann. Res. Rev. Biol., p. 962 - 977, v. 4(6), 2013.

45. Manorenjitha, M.S.; Norita, A.K.; Norhisham, S.; Asmawi, M.Z. GC-MS analysis of bioactive components of Ficus religiosa (linn.) stem. International Journal of Pharmacology and Biosciences, p. 99 - 103, v. 4(2), 2013.

46. Medeiros, M.B.; Prado, L.A.; Fernandes, V.C.; Figueiredo, S.S.; Coppede, J.; Martins, J.; Fiori, G.M.; Martinez-Rossi, N.M, .; Beleboni, R.O.; Contini, S.H.; Pereira, P.S.; Fachin, A.L. Antimicrobial activities of indole alkaloids from Tabernaemontana catharinensis, Natural Product Communications, p. 193-196, v. 6(2), 2011.

47. Meyer, J.M.; Ryu, S.; Pendland, S.L.; Kanyok, T.P.; Danziger, L.H. In-vitro energy of paromomycin with metronidazole alone or metronidazole against Helicobacter pylori. J Antimicrob Chemother., p. 403 - 406, v. 43, 1999.

48. Moody, J.A.; Fasching, C.E.; Peterson, L.R.; Gerding, D.N. Ceftazidime and amikacin alone and in combination against Pseudomonas aeruginosa and Enterobacteriaceae. Diagn. Microbiol. Infect. Dis., p. 59-67, v. 6, 1987.

49. Murray, H.W.; Berman, J.D.; Davies, C,R.; Saravia, N,G. (2005) Advances in Leishmaniasis. The Lancet, 366, 1561 1577.

50. Muthulakshmi, A.; Jothibai, M.R.; Mohan, V.R. GC-MS Analysis of bioactive components of Feronia elephantum Correa (Rutaceae). J. Appl. Pharmaceut. Sci., p. 69 - 74, v. 2(2), 2012

51. Obeidat, M.; Shatnawi, M.; Al-alawi, M.; Al-Zu'bi, E.; AlDmoor, H.; Al-Quadah, M.; El-Qudah, J.; Otri, I. (2012) Antimicrobial activity of crude extracts of some plant leaves. Res. J. Microbiol., p. 59 - 67, v. 7, 2012.

52. Olajuyigbe, O.O.; Afolayan, A.J. (2011) In vitro antibacterial activities of the methanol extract of Ziziphus mucronata Willd. subsp. mucronata Willd. J. Med. Plants Res., p. 3791 3795 , v. 5(16), 2011

53. Olajuyigbe, O.O.; Afolayan, A.J. (2012) In vitro pharmacological activity of the crude acetone extract of Erythrina caffra Thunb: Antibacterial and antifungal assessment. J. Med. Plants Res., p. 1713 - 1720, v. 6(9), 2012.

54. Prindle RF. Phenolic compounds. In: block SS, ed. Disinfection, sterilization and preservation. Philadelphia: Lea \& Febiayger, p. 197 - 224, 1983.

55. Rosenthal, G.A. The biochemical basis for the deleterious effects of L-canavanine. Phytochem., p. 1055-1058, v. 30, 1991.

56. Sabrina, K.; Huffman, M.; Se' Venet, T.; Hladik, C.; Grellier, P.; Loiseau, P. (2006) Bioactive properties of plant species ingested by chimpanzees (Pantroglodytes schweinfurthii) in the Kibale National Park, Uganda. American J. Primatol., p. $51-71$, v. 68, 2006.

57. Samuelsson, G.; Bohlin, L. Drugs of natural origin. A Textbook of Pharmacognosy $5^{\text {th }}$ Edition, Swedish Pharmaceutical Press, Stockholm: p. 620, 2004.

58. Samuni-Blank, M.; Izhaki, I.; Dearing, M.D.; Gerchman, Y.; Trabelcy, B.; Lotan, A.; Karasov, W.H.; Arad, Z. Intraspecific Directed Deterrence by the Mustard Oil Bomb in a Desert Plant. Curr. Biol., p. 1218-1220, 22(13), 2012.

59. Saxena, M.; Saxena, J.; Nema, R.; Singh, D.; Gupta, A. Photochemistry of medicinal plants. J. Pharmacog. Phytochem., p. 168 - 180, v. 1(6), (2013).

60. Shanholtzer, C.J.; Peterson, L.R.; Mohn, M.L.; Moody, J.A.; Gerding, D.N. MBCs for Staphylococcus aureus as determined by macrodilution and microdilution techniques. Antimicrob. Agents Chemother., p. 214-219, v. 26,1984.

61. Shanmughapriya, S.A.; Manilal, A.; Sujith, S.; Selvin, J.; Kiran, G.S. Natarajaseenivasan. K. Antimicrobial activity of seaweeds extracts against multi-resistant pathogens. Ann. Microbiol., p. 535-541, v. 58, 2008

62. Singariya, P.; Kumar, P.; Mourya, K.K. Isolation of new steroids of Kala Dhaman grass (Cenchrus setigerus) and evaluation of their bioactivity. Int. J, Res. Pharmaceut. Sci., p. $678-684$, v. 3(4), 2012

63. Small, E.; Catling, P.M. Canadian medicinal crops. NRC Research Press, Ottawa, Ontario Canada. p. 240, 1999.

64. Sriranmsridharan, () GC-MS Study and Phytochemical profiling of Mimosa pudica linn. J. Pharmaceut. Res., 741742, 4(3), 2011.

65. Stamp, N. "Out of the Quagmire of Plant Defense Hypotheses.” The Quarterly Rev. Biol., p. 23-55, v. 78(1), 2003.

66. Stead, D.A. Current methodologies for the analysis of aminoglycosides. J. Chromatog., p. 69 - 93. v. 747, 2000.

67. Sudha, T.; Chidambarampillai, S.; Mohan, V.R. GC-MS analysis of bioactive components of aerial parts of Kirganelia reticulata poir (Euphorbiaceae). J. Curr. Chem. Pharmaceut. Sci., p. 113-122, v. 3(2), 2013. 
68. Sundar, L.; Chang. F.N. (1993) Antimicrobial activity and biosynthesis of indole antibiotics produced by Xenorhabdus nematophilus.

69. Tanaka, J.C.; Silva, C.C.; Oliveira, A.J.; Nakamura, C.V.; Filho, B.P.; Antibacterial activity of indole alkaloids from Aspidosperma ramiflorum. Brazilian J. Med. Biol. Res. p. 387 - 391, v. 39(3), 2006

70. Teke, G.N.; Kuiate, J.R., Kuete, V.; Teponno, R.B.; Tapondjou, L.A.; Vilarem, G. Antidiarrheal activity of extracts and compound from Trilepisium madagascriense stem bark. Indian J. Pharmacol., p. 157 - 163, v. 42(3), 2010.

71. Teke, G.N.; Kuiate, J.R.; Kuete, V.; Tepomo, R.B.; Tapondjou, L.A.; Tane, P.; Giacinti, G.; Vilarem, G. Bioguided isolation of potential antimicrobial and antioxidant agents from the stem bark of Trilepisium madagascariense. South Afr. J. Bot., p. 319 - 327, v. 77(2), 2011.

72. Tiwari, R.; Chakraborty, S.; Saminathan, M.; Dhama, K.; Singh, S.V. Ashwagandha (Withania somnifera): Role in safeguarding health, immunomodulatory effects, combating infections and therapeutic applications: A review. J. Biol. Sci., p. 77-94, v. 14, 2014.

73. Upadhyay, A.; Upadhyaya, I.; Kollanoor-Johny, A.; Venkitanarayanan, K. Combating pathogenic microorganisms using plant-derived antimicrobials: A minireview of the mechanistic basis. BioMed Res. Int Article, ID 761741, 2014. http://dx.doi.org/10.1155/2014/761741.

74. Velmurugan, S.; Babu, M.M.; Punitha, S.M.; Viji, V.T.; Citarasu, T. (2012) Screening and characterization of antiviral compounds from Psidium guajava Linn. root bark against white spot syndrome virus. Indian J. Nat. Prod. Res., p. $208-214$, v. 3(2), 2012.

75. Wadood, A.; Ghufran, M.; Jamal, S.B.; Naeem, M.; Khan, A.; Ghaffar, R.; Asnad. Phytochemical analysis of medicinal plants occurring in local area of Mardan. Biochem. Anal. Biochem., 2: 144, 2013.

76. Wikler, M.A. Performance Standards for Antimicrobial Susceptibility Testing; Seventeenth Informational Supplement: Part M2-A9. M100-S17; C.L.S.I. (Clinical and Laboratory Standard Institute): Pennsylvania, PA, USA, 2007.

77. Wikler, M.A. Performance Standards for Antimicrobial Susceptibility Testing; Eighteenth informational supplement; M100-S18; C.L.S.I. (Clinical and Laboratory Standard Institute): Pennsylvania, PA, USA, p. 46-52, v. 28(1), 2008

78. Zhu, W.M.; He, H.P. Fan, L.M.; Shen. Y.M.; Zhou, J.; Hao, X.J. Components of stem barks of Winchia calophylla A. DC. and their bronchodilator activities. J. Integ. Plant Biol., p. $892-896$, v. $47(7), 2005$. 